\title{
IMPACT OF CERTAIN HEAVY METALS ON THE GILL AND LIVER OF THE NILE TILAPIA (OREOCHROMIS NILOTICUS)
}

\author{
Hanan S. Gaber \\ National Institute of Oceanography and Fisheries, Cairo, Egypt.
}

Keywords: heavy metals, toxicity, histopathology, gill, liver, Nile tilapia.

\begin{abstract}
The effect of the heavy metals $\mathrm{Cu}, \mathrm{Zn}, \mathrm{Cd}$ and $\mathrm{Pb}$ on the gill and liver tissues of the Nile tilapia, Oreochromis niloticus was examined in the laboratory. One hundred and fifty adult fish were divided into five groups (control, copper, zinc, cadmium and lead) each group containing 30 fish. They were continuously exposed to sub- lethal concentration of each metal $(1 \mathrm{mg} / \mathrm{L})$ for a period of 10 days. From each group, the gills and liver of six fish were removed after 10 days and the remaining fish were transferred to tap water for:a recovery period (21days). The tissue samples of gills and liver of both treated and recovery fish were dissected for histological examination. The results showed that the extent of distortion of the gills and liver was more pronounced in the fish group that were exposed to $\mathrm{Cd} \& \mathrm{~Pb}$.
\end{abstract}

\section{INTRODUCTION}

Cadmium and lead have no known role in biological systems, whereas copper and zinc are essential elements of enzymes or metalloproteins in fish metabolism (Olsson et al., 1998). Heavy metals are considered natural trace components of the aquatic environment, but their ground levels in the environment have been increased, especially at the industrial and agricultural fields, as well as mining activities (Langston, 1990; Bryan \& Langston, 1992). Many studies were carried out on different fish species and revealed that both essential ( $\mathrm{Cu} \& \mathrm{Zn}$ ) and nonessential $(\mathrm{Cd} \& \mathrm{~Pb})$ metals cause toxic effects in fish through disturbing the physiological activities (Naidu et al., 1984 ; Grobler et al .,1989; Kraak et al., 1994), biochemical processes (Dange, 1986 ; Canli, 1996 ; Soliman et al., 2004), reproduction and growth (Collvin, 1985 ; Weis \& Weis, 
1989 ; Kertész \& Fràncsi, 2003) and finally lead to their mortality (Canli $\&$ Erdem, 1994).

The histopathological changes caused by heavy metals, in gills, liver, kidneys, gonads and other organs of fishes have been reported by Blanton \& Robinson (1973), Kraak et al. (1994), Banerjee \& Chandra (2005), Olojo, et al. (2005) and Benjamin \& Handy (2006). Mallatt (1985) stated that all classes of irritant-heavy metals and organic toxicants have induced similar disorders indicated by lesions.

The effect of $\mathrm{Cu}$ on the gills of winter flounder, Pseudopleuronectas amricanus caused gill epithelium disorientation increase in number and size of chloride cells, hypertrophy and hyperplasia of epithelial cells, fusion of gill lamellae, decrease the number of mucus cells and chloride cells appear instead (Baker, 1969; Daoust et al., 1984). Zinc, on the other hand induced detachment of epithelium from the underlying pillar system, fusion of secondary lamellae and vasoconstriction in Salmo gairdneri (Tuurala \& Soivio, 1982 ; Lappivaara et al., 1995) and Channa striata (Banerjee \& Chandra ,2005).

The effects of $\mathrm{Cd}$ on zebra fish (Brachyclanio rerio) and rainbow trout Oncor thynchus mykiss fish were investigated (Gardner \& Yevich, 1970.; Oronsay \& Brafield, 1984; Karlsson et al., 1985). They recorded hyperplasia of gill epithelium, decrease in mucus secretions and increased number of chloride cells when exposed to $\mathrm{Cd}$, but later tended to decline.

Balah et al. (1993) observed hyperplasia of epithelial cells covering the secondary lamellae, oedema with separation of respiratory epithelium, dilation of lamellar blood vessels, as well as desquamation of epithelial covering after long term exposure of Oreochromis niloticus to lead acetate. Olojo et al. (2005) recorded an increase in intracellular vacuolation with edematous changes in the gill of Clarias gariepinus exposed to $0.08 \mathrm{mg} / \mathrm{L}$ lead for nine days. Alvarado et al. (2006) observed that exposure of turbot (Scophthalmus maximus) to $\mathrm{Cu}, \mathrm{Cd}$ and $\mathrm{Zn}$ led to increase the total number of chloride cells in the gills. After depuration period for $\mathrm{Cd}$, the total number of chloride cells was greatly reduced; however, they were slightly reduced after $\mathrm{Zn}$-exposure. Benjamin and Handy (2006) showed normal structure of gill of $O$. niloticus in the recovery phase of the experiment from $\mathrm{Cu}$.

The liver, on the other hand, is considered the main detoxifying organ, thus it is important to study the pathological changes in the hepatocytes exposed to heavy metals. In the teleost fish, Heteropnustes fossils and Tilapia mossambicus, the liver showed conspicuous changes in 
IMPACT OF CERTAIN HEAVY METALS ON THE GILL AND 81 LIVER OF THE NILE TILAPIA (OREOCHROMIS NILOTICUS)

the centrolobular area, cord disarray and connective tissues damage, as well as focal necrosis (Gbem et al., 2001). Olojo et al. (2005) observed patchy degeneration and isolated degenerated elements around the parenchyma cells with progressive increases of fibro connective tissue and congestion of the sinusoids after exposure of Clarias gariepinus to $\mathrm{Pb}$ for 9 days. They observed also, acute and extensive necrosis of liver cells at prolonged exposure. Benjamin and Handy (2006) stated that the fatty change in the liver of $\mathrm{Cu}$ exposed fish, $O$. niloticus was noticed and exacerbated during the recovery phase of the experiment.

The Nile tilapia, Oreochromis niloticus is an important culture fish due to its great fecundity and has no feeding problems in uptake or elimination, which are considered the most important factors in the metal metabolism and hence, metal toxicity. However, the majority of studies have been focused on uptake and recovery. Thus this investigation aimed to compare the histopathological changes of gills and liver of $O$. niloticus for two essential metals ( $\mathrm{Cu} \& \mathrm{Zn}$ ) and two non-essential metals ( $\mathrm{Cd} \&$ $\mathrm{Pb}$ ) following sub-lethal exposure and recovery.

\section{MATERIALS AND METHODS}

\section{The experimental animal}

One hundred and fifty of the Nile tilapia fish, Oreochromis niloticus (about 11 to $13.3 \mathrm{~cm}$ in length and 20.4 to $34.69 \mathrm{~g}$ in weight) were collected from Nawa fish farm and transferred in tanks for acclimatization for one month at the Faculty of Agriculture EL-Monoufya University.

The experimental design:

a. Treated groups:

The fish were divided into 5 groups (control, $\mathrm{cu}, \mathrm{zn}, \mathrm{cd} \& \mathrm{pb}$ ) in 15 glass aquaria (60 liters capacity) with stocking density of 10 fish / aquarium ( 3 aquaria for each group). The glass aquarium was filled with dechlorinated aerated tap water. Fish were exposed to minimal concentration ( $\mathrm{lmg} / \mathrm{L}$ ) of each of $\mathrm{Cu}$ (copper sulphate), $\mathrm{Zn}$ (zinc sulphate), $\mathrm{Cd}$ (cadmium chloride) and $\mathrm{Pb}$ (lead acetate), that are less than the permissible limits, according to WHO, (1990).

The experiment run for 10 days at room temperature of $22 \pm 2^{\circ} \mathrm{C}$ and day light for $12 \mathrm{hr}$. The $\mathrm{pH}$ value of tap water used in the experiment was $8.0 \pm 0.3$ and the total hardness was $2.31 \pm 0.2 \mathrm{mg} \mathrm{Ca} \mathrm{Co3/L}$.

The fish were fed daily during experiment with artificial fish meal. The control group was run parallel with the experimental fish. The water 
in all experimental aquaria was changed with the same concentration every two days to avoid decline in the metal concentrations.

Two fish samples were taken randomly from each aquarium after 10 days of exposure for examination.

b. Recovery groups:

The remaining fish (24 of each group) were transferred to dechlorinated aerated tap water for recovery period (21 days) during which samples of two fish were taken at 7,14 and 21days

Histological examination

The tissues of gills and liver of both treated and recovery fish samples were dissected out and fixed in Bouin's solution for $24 \mathrm{hr}$. The tissues were then dehydrated in an ascending series of ethyl alcohol, cleared in xylene, embedded in paraffin wax and sectioned at $4-6 \mu \mathrm{m}$ thickness. The specimens were mounted on clear slides, stained with heamatoxylin and eosin and then examined using Olympus light microscope.

\section{Gills}

\section{RESULTS}

After 10-days, the gills of the control group appeared with a slight focal proliferation of interlamellar cells and some epithelial lifting was occasionally observed.(Fig.1).

\section{Copper treated group:}

After 10 days of the treated aquaria with $\mathrm{Cu}$, the gills showed many epithelial lifting and dilated primary lameliae with congested blood vessels (Fig. 2). However, after 7, 14 \& 21 days of recovery period drooping of the filaments, as well as curling of lamellae were observed. Also, hyperplasia of interlamellar epithelium and lamellar epithelial cell lifting appeared with an expanded chloride cells in different parts (Figs. $3 \& 4)$

\section{Zinc treated group:}

After 10 days of treated with $\mathrm{Zn}$, moderate hyperplasia, lifting of lamellar epithelium and elongate secondary lamellae with curling in many parts were noticed (Fig.5).

After 7 days of recovery period, the gills showed large spaces between secondary lamellae due to oedema leading to sloughing of epithelial cells and hypertrophy of the chloride cells (Fig.6). However, after 14 and 21 days of recovery from $\mathrm{Zn}$, the major changes were observed in fusion of adjacent secondary lamellae and detachment of the 
IMPACT OF CERTAIN HEAVY METALS ON THE GILL AND 83 LIVER OF THE NILE TILAPIA (OREOCHROMIS NILOTICUS)

epithelium from pillar system. Moreover, severe sloughing of the epithelial cells, with hypertrophy of chloride cells and lymphocytes infiltration were also noticed (Fig.7).

Cadmium treated group:

After 10 days of treated with $\mathrm{Cd}$, the gill filaments showed a separation between the epithelial cells and the underlying pillar system and dilated primary lamellae with severe congestion of blood vessels (Fig.8).

After $7,14 \& 21$ days of recovery period, the gill filaments appeared with hyperplasia of epithelial cells between secondary lamellae, mucus secretion and severe congestion of blood vessels of the primary lamellae, as well as, aneurisms (Figs. $9 \& 10$ ).

Lead treated group:

After 10 days of treated with $\mathrm{Pb}$, the gills showed large subepithelial spaces, thin but much elongated secondary lamellae with disintegrated epithelial lining (Fig.11).

After 7 days of recovery period, the gill filaments appeared with severe hyperplasia, causing fusion of adjacent lamellae, deformed pillar system, infiltration of lymphocytes and severe hypertrophy of chloride and mucus cells (Fig. 12).

However, severe damage after more than 7 days of recovery period was observed after $14 \& 21$ days (Fig.13).

Liver

In the control group, no histopathologic lesions were observed (Fig.14). In each treated group with ( $\mathrm{Cu}, \mathrm{Zn}, \mathrm{Cd} \mathrm{\&} \mathrm{Pb}$ ) a moderate to severe dystrophy in the form of hepatic necrosis was observed.

\section{Copper and Zinc treated groups:}

After 10 days of treated with $\mathrm{Cu}$, the hepatocytes showed vacuolar degeneration with a faint eosinophilic cytoplasm and aggregation of the nuclei toward blood sinusoids (Fig.15). The same features were observed in those exposed to $\mathrm{Zn}$ (zinc sulphate), as well as the presence of degenerated pancreatic acini filled with hyaline substances. (Fig18).

After 7 days of recovery period from ( $\mathrm{Cu} \& \mathrm{Zn}$ ), hepatic degeneration and focal necrosis with hyperplasia of pyknotic nuciei were noticed (Figs.16 \& 19). However, after 14 and 21 days of recovery period, a moderate disorganization of hepatic cords, damage of the cell membrane in some area and dilated $\&$ congested blood vessels were reported in case of $\mathrm{Cu}$ treatment and fibrosis as well as necrosis was observed after $\mathrm{Zn}$ exposure (Figs. $17 \& 20$ ). 


\section{Cadmium and Lead treated groups:}

After 10 days of treated with $\mathrm{Cd}$ and $\mathrm{Pb}$, the liver showed severe disorganization of the hepatic cords, damage cell membrane, and hyperplasia of nuclei with eosinophilic granular cytoplasm. In addition to the above lesions, fibrosis also appeared in the liver treated with $\mathrm{Cd}$ (Fig. 21). However, severe inflammation due to dilated veins, filled with blood cells; and dilated sinusoids with hyaline degeneration were also noticed in the liver exposed to $\mathrm{Pb}$ (Fig. 24).

After $7,14 \& 21$ days of recovery from $\mathrm{Cd}$, the main common features were focal necrosis and dilated sinusoids with severe congestion (Fig. 22).

After 7 days of recovery period from pb, severe coagulative necrosis and lymphocyte infiltration were observed (Fig. 25).

After 14 and 21 days of recovery from pb, the lesions of liver hepatocytes included vacuolar degeneration, pyknotic nuclei and severe necrosis (Fig. 26).

\section{DISCUSSION}

The present investigation demonstrate the impact of chronic toxicity of both essential ( $\mathrm{Cu} \& \mathrm{Zn}$ ) and non-essential ( $\mathrm{Cd} \& \mathrm{~Pb}$ ) elements on gill and liver of Oreochromis niloticus .

\section{Gills}

The gills are considered the main site of entry for the dissolved metals. Thus they represent the target for the toxic action of metals (Evans, 1987 and Olsson et al., 1998). However, the variety of cell-types of the gills (chloride cells, mucus cell, pillar cells and undifferentiated cells) makes it difficult to interpret the possible mechanisms of metal accumulation (Alvarado et al, 2006).

Gills of the present fish showed epithelial cell lifting (oedema), proliferated chloride cells and congestion of the primary lamellae after exposure to both essential $(\mathrm{Cu} \& \mathrm{Zn})$ and non-essential $(\mathrm{Cd} \& \mathrm{~Pb})$ elements; however a drastic effect was observed for the latter elements . These lesions are nearly similar to the structural changes, which have been described by many investigators (Skidmore \&Tovell, 1972.; Daoust \& Freguson, 1985.; Roberts, 1989.; Nowak \& Munday, 1994.; Pelgrom et al., 1994.; Clark et al., 1997.; Mazon et al., 1999.; Banerjee \& Chandra, 2005). Such lesions represent the limited responses of fish gill to heavy metal (Mallatt, 1985). 
IMPACT OF CERTAIN HEAVY METALS ON THE GILL AND 85

LIVER OF THE NILE TILAPIA (OREOCHROMIS NILOTICUS)

In the present study, the cell strategy during recovery period ( 7 , 14 and 21 days) after $\mathrm{Cu} \& \mathrm{Zn}$ exposure was represented by vasoconstriction proliferation and hypertrophy of chloride cells and mucus cells, curling and abnormal elongation of the secondary lamellae, severe inter-epithelial oedema and deformed pillar system. These responces were reported by Skidmore (1970), Skidmore and Tovell (1972), Tuurala \& Soivio (1982) and Van Heerden et al. (2004). These responses resulted in decreased oxygen tension in the blood or might be connected to a disorder in osmoregulation. Skidmore and Tovell (1972) suggested that the physiological significances and vasoconstriction represent a protective mechanism against the loss of osmotic stability normally maintained by epithelium. Dang et al. (2004) found that the increased number of chloride cells, resulting from hypertrophy led to increased necrosis and apoptosis.

Zinc exerts its toxicity partially by interfering with $\mathrm{Cu}$ metabolism (National Research council, 1980; Sileo et al., 2004). Lappivaara et al. (1995) reported that the recovery of arterial oxygen tension occurred despite the fact that the gill structure had not fully recovered from $\mathrm{Zn}$ during $48 \mathrm{hr}$ of exposure, but it takes approximately week for doubling of the gill epithelial cell protein content in culture (Pärt et al., 1993). Also it was apparent that $\mathrm{Zn}+^{2}$ is a competitive inhibitor of calcium pump (Shephard \& Simkiss, 1978).

In the present study, the treated groups with non-essential elements (Cd \& $\mathrm{Pb}$ ) showed a degeneration of gills, as well as architectural distortion and abnormal elongation, most probably, as a result of oedema These findings simulate the observations of Olojo (2005) who reported that complete edematous separation of the respiratory epithelium which leads to lamellar epithelial necrosis in fish treated with $\mathrm{Pb}$ causing osmoregulatory stress (Smith \& Piper, 1975).

In the present study, after 7, 14 and 21 days of recovery from (Cd $\& \mathrm{~Pb}$ ), the gills showed severe degeneration, hyperplasia and led to adjacent secondary lamellar fusion, hypertrophied chloride and mucus cells, as well as lamellar aneurism with severe congestion in case of $\mathrm{Cd}$ recovery period. Mazon et al. (2002) showed lamellar aneurism in Pronchilodus gills after exposure to $\mathrm{Pb}$ and $\mathrm{Cu}$. Martinz et al. (2004), stated that heavy metals were associated with lamellar aneurism lesion that seems to involve pillar cell disruption.

In case of $\mathrm{Pb}$ recovery aquaria, the gills had degenerated pillar system with necrotic cells and lymphocytes infiltration. These lesions are similar to those reported by Olojo et al. (2005). Such histopathological 
alterations reflect water quality and the health status in fish (Laurent \& Perry, 1990; Cerqueria \& Fernandez, 2002).

Liver

The histological examination of the normal liver tissue comprises strands of hepatic cells, which are large in size, hexagonal in shape with more or less centrally located nuclei and homogenous cytoplasm.

Ten days of exposure to essential elements $(\mathrm{Cu} \mathrm{\& Zn)}$ resulted in extensive vacuolation of parenchyma hepatocytes, pyknotic nuclei and few focal necrosis of hepatic cells. Similar changes have been reported by Sorensen et al. (1984) after treatment of the fish from Belews Lake with selenium. Baker (1969) reported that sub-Iethal exposure of the winter flounder Pseudopleuronectes americanus to $\mathrm{Cu}$ produces fatty cells around the central vein. Moreover, Skidmore (1964 \& 1970) and Shaw \& Handy (2006) reported that Nile tilapia accumulates excess $\mathrm{Cu}$ in the liver and intestine and consequently shows a decline in growth and nutritional performance which are associated with liver pathology. They added that the liver, showed fatty change, characterized by increasing lipid deposits and a consequently loss of sinusoid space, Handy (2003) suggested that Increased lipid content of the liver could be explained by either increased deposition of lipid in excess of nutritional requirements or a failure to mobilize lipid stores during dietary $\mathrm{Cu}$ toxicity. Crandall \& Goodnight (1963) and Gardner \& Yevich, (1970) reported that $\mathrm{Zn}$ induced severe fatty degenerative changes in the liver.

After 7,14 and 21 days of recovery period to these essential elements, cell necrosis with eccentric and pyknotic nuclei, degenerative cytoplasm, rupture of blood sinusoids and lymphocyte infiltration were observed. Lemly (2002) showed the same lesions in fish of Belews Lake contaminated by selenium. Moreover, Shaw and Handy (2006) stated that liver of Nile tilapia did not recover quickly from $\mathrm{Cu}$ and showed further increases in $\mathrm{Cu}$ content and fatty degeneration during the recovery period.

In the present study, the groups treated with $(\mathrm{Cd} \& \mathrm{~Pb})$ showed various degrees of hepatic degeneration, focal necrosis and severe sinusoidal congestion.

After 7, 14, and 21 days of recovery, the hepatic necrosis and hepatic fibrosis were increased. Similar observations have been reported in the liver of catfish after 9 days of exposure to $\mathrm{Pb}$ (Olojo et al., 2005). Gbem et al. (2001) noticed high accumulation of $\mathrm{Pb}$ in the liver and suggested that it is related to role of the liver in accumulation and detoxification. Kertész \& Fráncsi (2003) and Pacheco \& Santos (2005) 
IMPACT OF CERTAIN HEAVY METALS ON THE GILL AND 87 LIVER OF THE NILE TILAPIA (OREOCHROMIS NILOTICUS)

and stated that the dissociation between hepatocytes and disorganization of hepatic cords in the liver of bleached Kraft pulp mill effluent treated mallard fish group of to $\mathrm{Cd}, \mathrm{Cr}$ and $\mathrm{Pb}$, probably related to cell necrosis, and degeneration of structural proteins in the hepatocyte membrane.

Metal accumulation in the fish tissues varies according to the rates of uptake, storage and elimination (Heath, 1987 and Langston, 1990). This means that metals which have high uptake and low elimination rates in the tissues of fish are expected to be accumulated to higher levels. The accumulation of non-essential metals may occur at very low environmental concentration because fish are not able to regulate their level (Larsson et al., 1985; Heath, 1987; Mustafa \& Canli, 2000). Jeantet et al. (1997) and Baer et al. (2005) observed that tissue alterations could be observed even with low concentrations of trace metals. The results of the present study suggest that once the non-essential metal $\mathrm{Zn}$ caused damage in the tissue of fish, it is difficult to recover. However, a healthy change caused by $\mathrm{Cu}$ in the tissue during the recovery period, suggests that the tissues of $O$. niloticus regulate their $\mathrm{Cu}$ level better than $\mathrm{Zn}, \mathrm{Cd}$ and $\mathrm{Pb}$ and no recovery progress could be observed during the recovery period that is because that the effect of heavy metals appeared after prolonged time

\section{REFERENCES}

Alvarado, N. E.; Quesada, I.; Hylland, K.; Marigómez, I. and Soto, M. (2006). Quantitative changes in metallothionein expression in target cell-types in the gills of turbot (Scophthalmus maximus) exposed to $\mathrm{Cd}, \mathrm{Cu}, \mathrm{Zn}$ and after adepuration treatment. Aqutic. Toxicol., 77: 64-77.

Baer, V. H.; Audet, C. and Pellerin, J. (2005). Investigations on health of Anadromous Arctic char (Salvelinus alpinus) from the eastern Canadian arctic ecosystem J. Rech. Oceonographique. 30. (1-2): 1-11.

Baker, J. T. P. (1969). Histological and electron microscopical observations on copper poisoning in the winter flounder (Pseudoplerrnectes amricanas) J. Fish. Res. Board Can., 26: 2785-2793. 
Balah, A. M.; ElbouhY, Z. M. and Easa, M. E. (1993). Histologic and histopathologic studies, on the gills of Tilapia nilotica (Oreochromis niloticus) under the effect of some heavy metals. Zag. Vet. J., 21(3): 351-364

Banerjee, T. K. and Chandra, S. (2005). Estimation of zinc chloride contamination by histopathological analysis of the respiratory organs of the air breathing "murrel" Channa striata (Bloch, 1797) (Channiformes, pisces). Veterinarski Arhiv, 75 (3) 253-263.

Benjamin, J. S. and Handy, R. D. (2006). Dietary copper exposure and recovery in Nile tilapia, Oreochromis niloticus. Aquatic Toxicol, 76: $111-121$

Blanton, W. G. and Robinson, M. C. (1973). Some acute effects of low boiling petroleum fractions on the cellular structures of fish gills under field conditions. In "The microbial degeneration of oil pollution" Ahearn, G.G. \& Meyers, S.P., pp. 265-273

Bryan, G. and Langston, W. J. (1992). Bioavailability, accumulation and effects of heavy metals in sediments with special refrence to United Kingdom estuaries: a review. Environ. Pollut., 7: 89-131.

Canli, M. (1996). Effects of mercury, chromium and nickel on glycogen reserves and protein levels in tissues of Cyprinus carpio. Tr. J. Zool., 20: 161-168.

Canli, M. and Erdem, C. (1994). Mercury toxicity and effects of exposure concentration and period on mercury accumulation in tissues of a tropical fish Tilapia nilotica (L) Tr. J. Zool.,18: 233-239.

Cerqueira, C. C. C. and Fernandez, M. N. (2002). Gill tissue recovery after copper exposure and blood parameter responses in the tropical fish Prochilodus scrofa. Ecotoxicol. Environ. Saf., 52: 8391.

Clark, A.; Nowak, B.; Handlinger, J.; Munday, B.L. and Percival, S. (1997). Clubbing and necrosis gill (CNG) syndrome in sea-caged Atlantic salmon, Salmo salar L., in Tasmania: an initial report. J. Fish .Diseas., 20: 59-68. 
IMPACT OF CERTAIN HEAVY METALS ON THE GILL AND 89 LIVER OF THE NILE TILAPIA (OREOCHROMIS NILOTICUS)

Collvin, R. J. (1985). Affects of copper on growth and starvation in perch, Perca fluviatillis L. J. Fish. Biol., 27: 757-764.

Crandall,C. A. and Goodnight, C. J. (1963). The effects of sub lethal concentrations of several toxicants in the common guppy, Lebistes reticulates. Trans. Amr. Microsc. Sac. 82: 59-73.

Dang, Z.; Balm, P. H. M.; Flik, G.; Wendelaar-Bonga, S. L. and Lock, R. A. (2004). Cortisol increases $\mathrm{Na}+\mathrm{K}+\mathrm{ATPase}$ density in plasma membranes of gill chloride cells in the fresh water Tilapia (Oreochromis mossambicus). J. Exp. Biol., 203: 2349-2355.

Dange, A. D. (1986). Changes in carbohydrate metabolism in Tilapia Oreochromis mossambicus (saratherodon), during short-term exposure to different types of pollutants. Environ. Poll., 41: 165177.

Daoust, P. Y.; Wobesor, G. and Newstead, J. D. (1984): Acute Histopathological effects of inorganic mercury and copper in gills of rainbow trout. Vet. Pathol., 21: 93-101

Daoust, P. Y. and Ferguson, H. W. (1985). Nodullar gill disease: a unique form of proliferate gill disease in rainbowtrout, Salmo gairdneri Richardson. J. Fish. Diseas., 8: 511-522.

Evans, D. H. (1987). the fish gill: site of action and model for toxic effects of environment. pollu. Environ. Health Perspect., 71: 47-58.

Gardner, G. P. and Yevich, P. P. (1970). Histological and hematological responses of estuarine teleosts to cadmium. J. Fish. Res. Board Can., 27: 2185-2196.

Gbem, T. T.; Balogun, J. K.; Lawal, F. A. and Annune, P. A. (2001). Trace metal accumulation in Clarias garepinus exposed to sub lethal levels of tannery effluent. Sci. Total Environ. $271: 1-9$.

Grobler, E.; Du Perez, H. H and Van Vuren, J. H. J. (1989). Toxic effects of zinc and iron on the routine oxygen consumption of Tilapia spanmani Cichilidae., Comp. Biochem. Physiol., 9(1): 207-214. 
Handy, R. D. (2003). chronic effects of copper exposure versus endocrine toxicity: two sides of the same toxicology process? Comp. Biochem. Physiol. 135A: 25-38.

Heath, A. G. (1987). Water pollution and fish physiology. C R C. Press, $245 \mathrm{pp}$. Florida, USA.

Jeantet, A. Y.; Ballan-Du Francais, C. and Anglo, A. (1997). Pollution par les métaux et atteintes cytologiques chez les bivalves marins. In Biomarqueurs en ecotoxicologie. Aspects fondametaux. LAGADIC., CAQUET, T., AMIARD, J.C\& RAMADE, F.(eds.) . Paris: Masson: pp.315-353.

Karlsson, N. L.; Runn, P.; Hanx, C. and Forlin, L. (1985) . Cadmiuminduced changes in gill morphology of zebra fish, Brachydanio rerio (Hamilton-Buchman) and rainbow trout, Salmo gairdneri Richadson. J. Fish Biol., 27: 81-95

Kertész, V. and Fráncsi, T. (2003). Adverse effects of (surface water pollutants) $\mathrm{Cd}, \mathrm{Cr}$ and $\mathrm{Pb}$ on the embryogenesis of the mallard. Aquatic Toxicol., 65: 425-433.

KraaK, M .H. S.; Wink, Y. A.; Stuijzand, S. C.; Buckert-De Jong, M.C.; De Groot, C. J. and Admiraal, W. (1994). Chronic ecotoxicity of $\mathrm{Zn}$ and $\mathrm{Pb}$ to the zebra mussel Dreissena polymorpha. Aquatic. Toxicol ., 30:77-89.

Langston, W. J. (1990). Toxic effects of metals and the incidence of marine ecosystem, In: heavy metals in the Marine Environment (eds plmess RW, Rainbow PS),. CAC press, New York. 256 pp.

Lappivaara, J.; Nikinmaa, $\mathrm{M}$ and Tuurala, H. (1995). Arterial oxygen tension and the structure of the secondary lamellae of the gills in rainbow trout (Oncorhynchus mykiss) after acute exposure to zinc and during recovery. Aquat. Toxicol., 32: 321- 331.

Larsson, A.; Haux, C. and Spbeck, M. (1985).Fish physiology and metal pollution. results and experiences from laboratory and field studies. Ecotox. Environ. Saf., 9: 250-281. 
IMPACT OF CERTAIN HEAVY METALS ON THE GILL AND 91

LIVER OF THE NILE TILAPIA (OREOCHROMIS NILOTICUS)

Laurent, P. and Perry, S. F. (1990). The effects of cortisol on gill chloride cells morphology and ionic uptake on the freshwater trout, Salmo gairdneri. Cell tissue Res., 2: 259-442.

Lemly, A. D. (2002). Symptoms and implication of selenium toxicity in fish: The Belows Lake case example. Aquat. Toxi. 57: 39-49.

Mallat, J. (1985). Fish gill structural changes induced by toxicants and other irritants: a statistical review. Can. J. Fish. Aquatic. Sci., +2: 630-648.

Martinz, C. B. R. ; Nagae, M.Y.; Zaia, C.T.B.V. and Zaia, D. A. H. (2004). Acute morphological and physiological effects of lead in the Neotropical fish Prochilodus lineatus . Braz. J. Biol., 64 (4): 797-807.

Mazon, A. F.; Monteiro, E. A. S.; Pinheiro, G. H. D and Fernandez, M.N. (2002). Hematological and physiological changes induced by short-term exposure to Copper in the freshwater fish, Prochilodus scrofa. Braz. J. Biol., 62 (4A): 621-631.

Mazon, A. F.; Cerqueira, C. C. C.; Monteiro, E.A.S and Fernandez, M. N. (999). Acute copper in fresh-water fish: morphological and physiological effects. In: Biology of Tropical Fishes (Val, A.L., V.M.F. Almcida-vol, Eds.).INPA, Manaus, Brazil, pp. 261-275.

Mustafa, K. and Canli, M. (2000).Elimination of essential $(\mathrm{Cu}, \mathrm{Zn})$ and non-essential $(\mathrm{Cd}, \mathrm{Pb})$ from tissues of afresh water fish Tilapia zillii. Turk. G. Zool., 24: 429-436.

Naidu, K. A.; Abhinender, K. and Ramamuthi, R. (1984). Acute effect of mercury toxicity on some enzymes in liver of teleost Sarotherodon mossambicus. Ecotox. Environ. Saf., B : 215-218.

National Research Council (1980). Mineral tolerance in Domestic Animals. Washington, DC; National Academy of Sciences.

Nowak, B. F. and Munday, B. L. (1994). Histology of gills of Atlantic salmon during the first few months following transfer to sea water. Bull. Europ. Assoc. Fish. Pathol. 14: 77-81. 
Olojo, E. A. A.; Olurin, K. B.; MBAKA, G. and Oluwemimo, A. D. (2005). Histopathology of the gill and liver tissues of the African catfish Clarias gariepinus exposed to lead. African J. Biotech., 4 (1): 117-122.

Olsson, P. E.; Kling, P. and Hogstrand, C. (1998). Mechanisms of heavy metal accumulation and toxicity in fish. In: Langston, W.J., Bebianno, M.J. (Eds.), Metal metabolism in Aquatic Environments. Chapman and Hall, London, PP. 321-350.

Oronsaye, J. A. O. and Brafield, A. E. (1984). The effect of dissolved cadmium on the chloride cells of the gills of the stickleback Gastrosteus aculeatus L. J. Fish Biol., 25: 253-258

Pacheco, M. and Santo, A. M. (2005). Biotransformation, genetic and hisological effects of environmental contaminants in European eel (Anguilla anguilla L.). Ecotox. Environ. Saf., 53 : 331-347.

Pärt, P.L.; Norrgren, E.; Bergström and Sjöberg, P. (1993).Primary cultures of epithelial cells from rainbow trout gills. J. Exp. Biol., 175: 219-232.

Pelgrom, S. M. G. J.; Lameras, L. P. M.; Garritsen, J. A. M.; Pels, B.M.; Lock,R. A. C.; Balm, P. H. M. and Wendelaar Bonga, S. A.(1994). Interaction between copper and cadmium during single and combined exposure in juvenile Tilapia Oreochromis mossambicus : Influence of feeding condition on whole body metal accumulation and the effect of the metal on tissue water and ion content. Aquatic .Toxicol., 30: 117-135.

Roberts, R. J. (1989). The path physiology and systematic pathology of teleosts: the respiratory system. In: fish pathology $2^{\text {nd }}$ edn (Ed by R. J. Roberts), Bailliere Tindall, London. PP. 67-69.

Shaw, B.J and Handy, R.D. (2006). Dietary copper exposure and recovery in Nile tilapia Oreochromis niloticus. Aquatic. Toxicol., 76: 111121. 
IMPACT OF CERTAIN HEAVY METALS ON THE GILL AND 93 LIVER OF THE NILE TILAPIA (OREOCHROMIS NILOTICUS)

Shephard, K. and Simkiss, K. (1978) . The effects of heavy metal ions on $\mathrm{Ca}^{2}+$ ATP ase extracted from fish gills. Comp. Bioch. Physiol., 61b: 69-72.

Sileo, L. ; Nelson Beyer, W. and Mateo, R. (2004). Pancreatitis in Wild zinc-poisoned water fowl. Avian Pathology .32 (6): 655-660.

Skidmore, J.F. (1964). Toxicity of zinc compounds to aquatic animals with species reference to fish. Q. Rev. Biol., 39: 227-248.

Skidmore, J. F. (1970). Respiration and osmoregulation in rainbow trout with gills damaged by zinc sulphate. J. Exp. Biol., 32: 481-494. Skidmore, J. F. and Tovell, P. W. A. (1972). Toxic effects of zinc sulphate on gills of rainbow trout. Water Res., 3(B): 217-230.

Smith, C. E. and Piper, R. G. (1975). Lesions associated with chronic exposure to ammonia. In pathology of fishes. Eds We Ribelin. G. Migaki, Madison, wis. University of Wisconsin press. PP. 479514.

Soliman, M. F. M.; EL-Shenawy, N.S. and Ghobashy, M. A. (2004): Parasitology Aspects and biochemical changes of infected culured Tilapia (Oreochromis hybrid). Acta Ichthyological Et piscatorial 34 (1): 21-32.

Sorensen, E. M. B.; Cumbie, P. M. ; Bauer, T. L; Bell, J.S. and Harlan, A. (1984). Histopathological, hematological, condition-factor and organ weight changes associated with selenium a accumulation in fish from Belews lake, north Carolina. J. Environ. Contam. Toxicol., 13: 153-162.

Tuurala, H. and Soivio, A. (1982). Structural and circulatory changes in the secondary lamellae of Salmo gairdneri gills after sub lethal exposures to dehydroabietic acid and zinc. Aquatic Toxicol., 2: 21-29. 
Van Heerden, D.; Vosloo, A. and Nikinmaa, M. (2004). Effects of shortterm copper exposure on gill structure, metallothionein and hypoxia-indycible factor-1 $\alpha$ (HIF-1 $\alpha$ ) levels in rainbow trout (Oncorhynchus mykiss). Aquatic. Toxicol., 69: 271 -280.

Weis, J. S. and Weis, P. (1989). Effects of environmental pollutants on early fish development Rev. Aquat Sci. 1: 45-73.

WHO (1990). Review of potentially harmful substances: Cadmium, Lead, Tin (zinc). WHO report no. 22, Geneva. 
IMPACT OF CERTAIN HEAVY METALS ON THE GILL AND 95

LIVER OF THE NILE TILAPIA (OREOCHROMIS NILOTICUS)

\section{EXPLANATION OF FIGURS}

Fig.1: Photomicrograph of a transverse section of a gill filament of the control group showing the normal appearance of the primary lamellae (P) and secondary lamellae (S). (H\&E., X 650)

Fig.2: Photomicrograph of a transverse section of a gill 10 days of exposure to $1 \mathrm{mg} / \mathrm{L} \mathrm{Cu}$ (copper sulphate) showing dilated primar: lamellae $(\mathrm{P})$ with congested blood vessels.

(H\& E., X 650)

Fig.3: Photomicrograph of a transverse section of a gill after 7 days of recovery from $\mathrm{Cu}$ showing, hyperplasia of epithelial cells, curling of secondary lamellae (long arrows) and hypertrophied chloride cells (short arrows).

(H\&X., 650)

Fig.4: Photomicrograph of a transverse section of a gill after 21 days of recovery from $\mathrm{Cu}$ showing a slightly normal gill filament. Notice irregular shape of secondary lamellae $(\mathrm{S})$.

(H\& E., X 650)

Fig.5: Photomicrograph of a transverse section of a gill after 10 days of exposure to $1 \mathrm{mg} / \mathrm{L} \mathrm{Zn}$ (zinc sulphate) showing hyperplasia of epithelial cells $(\rightarrow)$ and elongate \& curling of secondary lamella (S). (H\& E., X 650)

Fig.6: Photomicrograph of a transverse section of a gill after7 days of recovery from $\mathrm{Zn}$ showing oedema $\left(^{*}\right)$, proliferation and hypertrophy of chloride cells (long arrows) and necrosis of oesinophilic epithelial cells (short arrows) (H \& E., X 650)

Fig.7: Photomicrograph of a transverse section of a gill after 21 days of recovery from $\mathrm{Zn}$ showing deformed pillar system with lymphocytes infiltration (L).

(H\& E., X 650)

Fig.8: Photomicrograph of a transverse section of a gill after 10 days of exposure to $1 \mathrm{mg} / \mathrm{L} \mathrm{Cd}$ (cadmium chloride) showing severe epithelial cell lifting (long arrows), dilated primary lamella (p) and hypertrophy of chloride cells (short arrows) (H\& E., X 650).

Fig.9: Photomicrograph of a transverse section of a gill after7 days of recovery from $\mathrm{Cd}$ showing severe oedema lead to sloughing of 
epithelial cells (long arrows)and fusion of adjacent lamellae (short arrows).

(H\& E., X 650)

Fig.10: Photomicrograph of a transverse section of a gill after 21 days of recovery from $\mathrm{Cd}$ showing hypertrophy of mucus cells $(\rightarrow)$ and lamellar aneurism $\left(^{*}\right)$.

(H\& E., X 650)

Fig.11: Photomicrograph of a transverse sections of a gill after 10 days of exposure to $1 \mathrm{mg} / \mathrm{L} \mathrm{Pb}$ (lead acetate) showing, hyperplasia leading to shortening secondary filaments(S) and dilated primary lamellae with congested blood vessel (B.V)

(H\&E., X 650)

Fig.12: Photomicrograph of a transverse section of a gill after 7 days of recovery from $\mathrm{Pb}$ showing severe hyperplasia of epithelial cells leading to fusion of adjacent lamellae(short arrows) and proliferation of mucus cells (long arrows) (H\& E., X 650)

Fig.13: Photomicrograph of a transverse section of a gill after 21 days of recovezy from $\mathrm{Pb}$ showing severe hypertrophy of chloride cells (long àrrows) and mucus cells (short arrows) and severe dilated primary lamellae $(\mathrm{P})$.

(H \&E., X 650)

Fig. 14: Photomicrograph of a section of the control liver showing normal appearance of the hepatic cords with oesinophilic cytoplasm and nucleus (short arrows) and sinusoids between them (long arrows). ( $\mathrm{H} \& \mathrm{E} ., \mathrm{X} 650)$

Fig.15: Photomicrograph of a section of the liver after 10 days of exposure to $\mathrm{Cu}$ showing vacuolated hepatic cells with faintly stained cytoplasm, aggregation of nuclei toward the sinusoids and increases in the number of kuppfer cells ( $\rightarrow$ ) (H\& E., X 160)

Fig.16: Photomicrograph of a section of the liver after 7 days of recovery from $\mathrm{Cu}$ showing vacuolated hepatic cells and early focal necrosis $(->)$ with fatty change $\left(^{*}\right)$

(H \&E., X 160)

Fig.17: Photomicrograph of a section of the liver after 21 days of recovery from $\mathrm{Cu}$ showing dilated blood vessels (B.V) with lymphocytes infiltration.

(H \& E., X 160) 
IMPAC'T OF CERTAIN HEAVY METALS ON THE GILL AND 97 LIVER OF THE NILE TILAPIA (OREOCHROMIS-NILOTICUS)

Fig.18: Photomicrograph of a section of the liver after 10 days of exposure to $\mathrm{Zn}$ showing vacuolar degeneration. Notice the lumen of the pancreatic acini's filled with hyaline material $(->)$. (H\&E., X160)

Fig.19: Photomicrograph of a section of the liver after 7 days of recovery from $\mathrm{Zn}$ showing extensive cellular disorganization and extensive focal necrosis $\left({ }^{*}\right)$ and pyknotic nuclei $(->)$. (H \& E. X 160) ,

Fig.20: Photomicrograph of a section of the liver after 21 days of recovery' from $\mathrm{Zn}$ showing severe necrosis and fibrosis $(->)$. (H\&E., X 160)

Fig.21: Photomicrograph of a section of the liver after 10 days of exposure to $\mathrm{Cd}$ showing disorganization of hepatic cords with pyknotic nuclei $(->)$ and fibrosis $\left({ }^{*}\right)$.

(H \&E., X 160)

Fig.22: Photomicrograph of a section of the liver after 7 days of recovery from $\mathrm{Cd}$ showing focal necrosis $\left(^{*}\right)$ and dilated sinusoids filled with lymphocytes $(->)$. (H\& E., X 160)

Fig.23: Photomicrograph of a section of the liver after 21 days of recovery from $\mathrm{Cd}$ showing damage of pancreatic acini $\left.{ }^{*}\right)(\mathrm{H} \& \mathrm{E} ., \mathrm{X} 160)$

Fig.24: Photomicrograph of a section of the liver after 10 days of exposure to $\mathrm{Pb}$ showing dilated sinusoids $(\rightarrow)$ with severe congestion, destructed hepatocytes around blood vessels (arrows). (H\& E., X 160)

Fig.25: Photomicrograph of a section of the liver after 7 days of recovery from $\mathrm{Pb}$ showing hyaline degeneration $(->)$ and hepatic necrosis $(*)$.

( $\mathrm{H} \& \mathrm{E}, \mathrm{X} \mathrm{160)}$

Fig.26: Photomicrograph of a section of the liver after 21 days of recovery from Cd showing severe necrosis (->). (H \& E., X 160) 


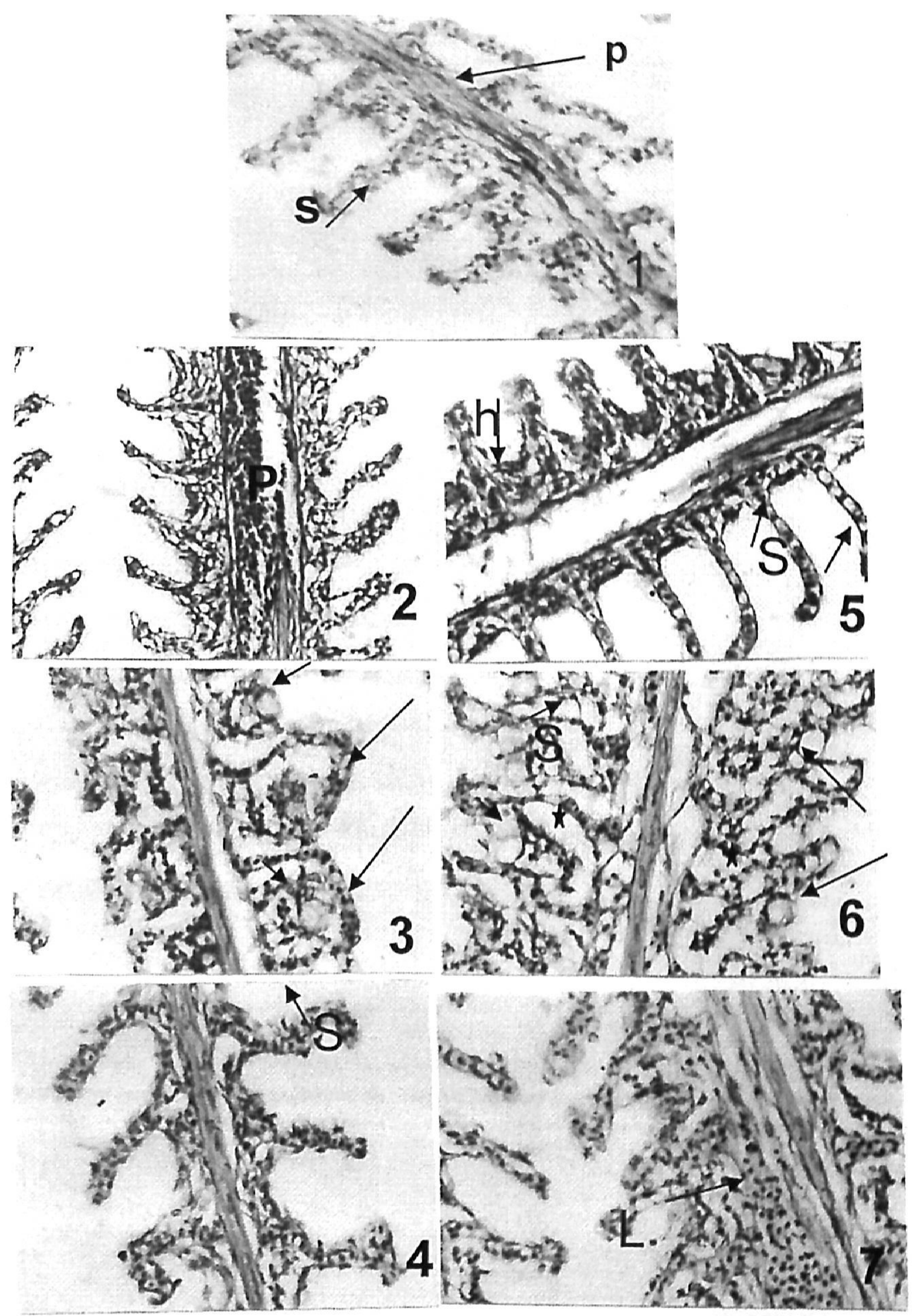



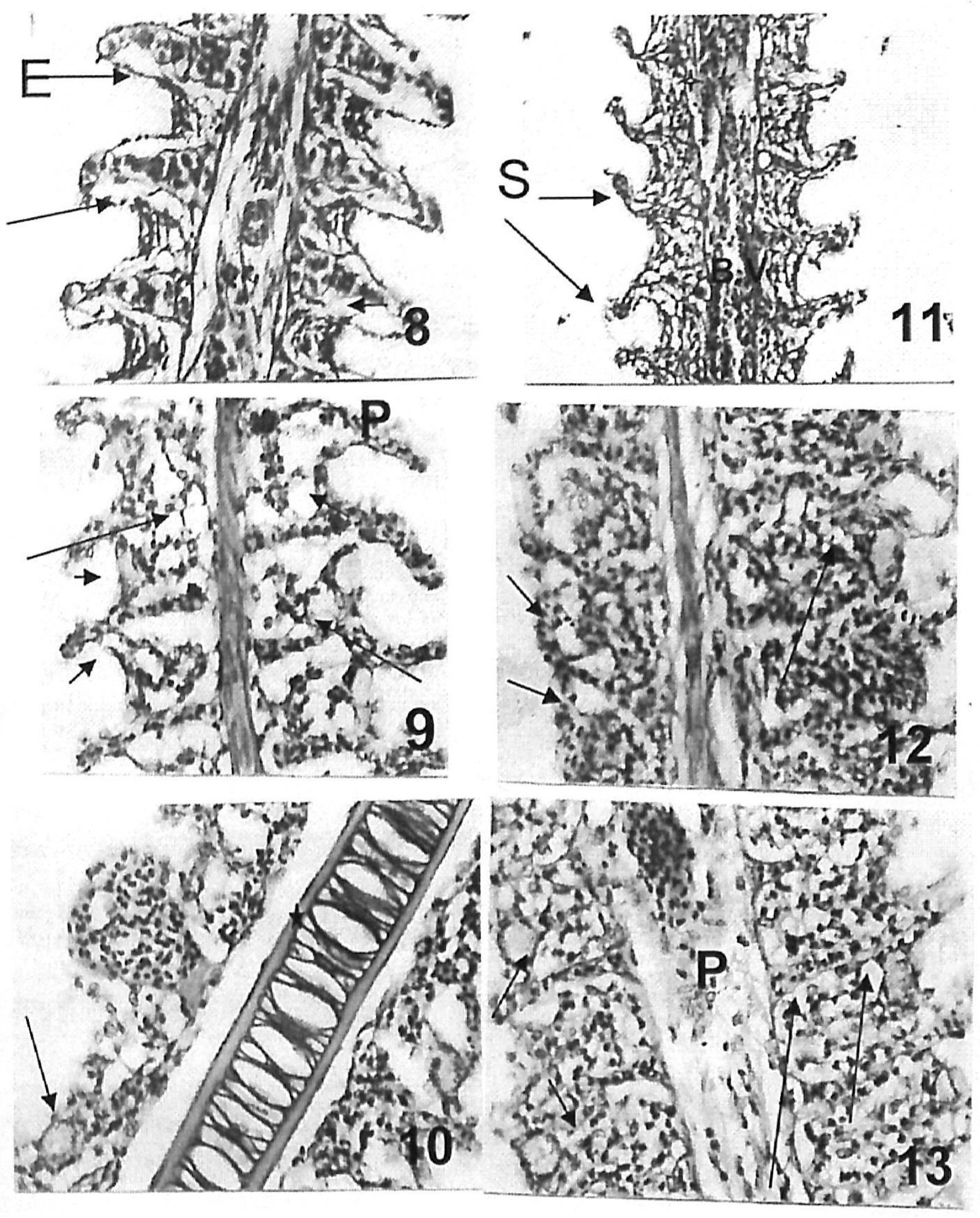


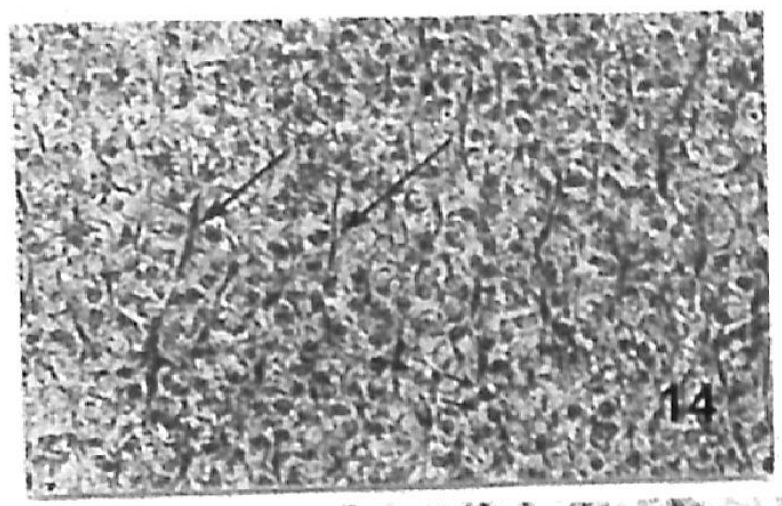

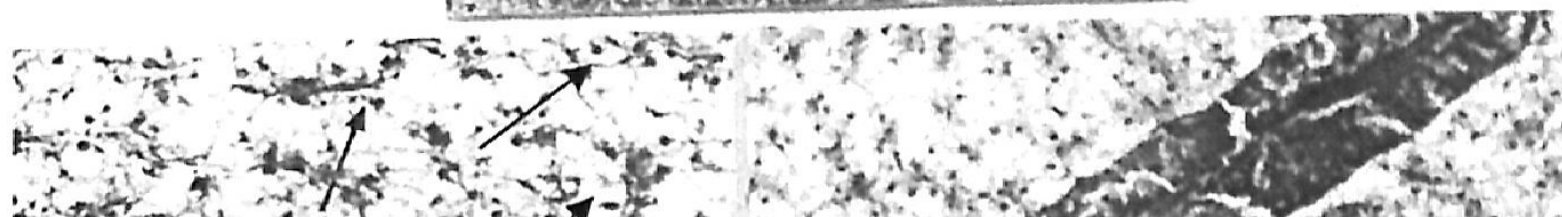

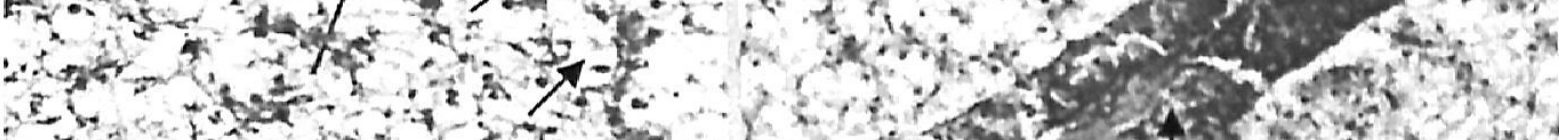

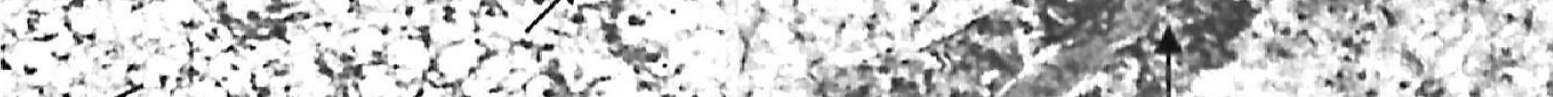

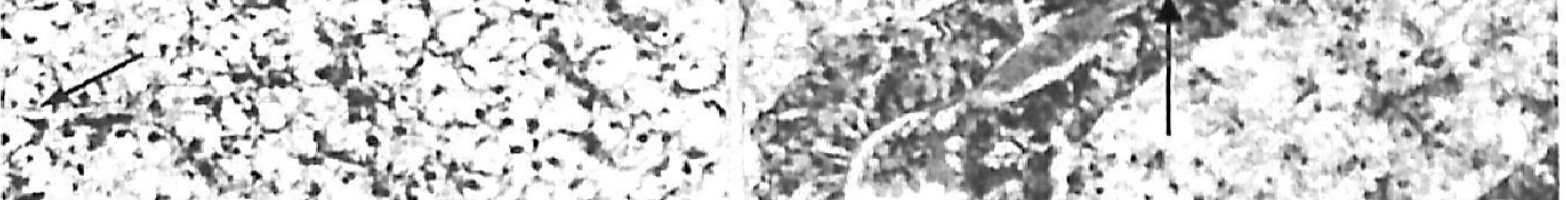

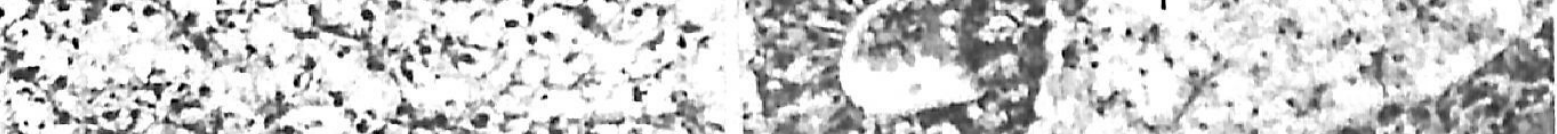

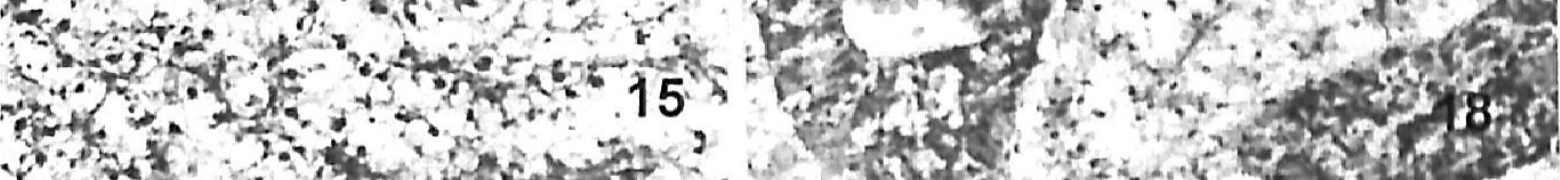

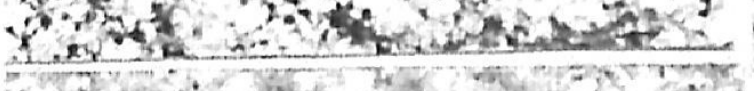

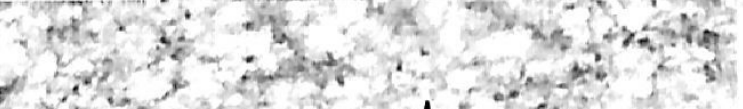

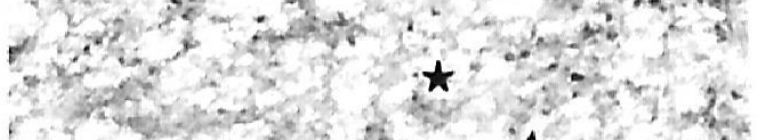

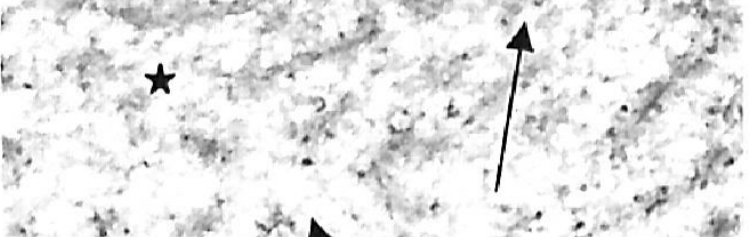
$\frac{1}{4}+16$

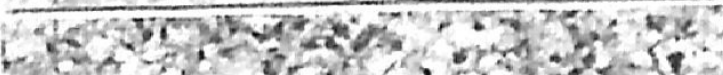

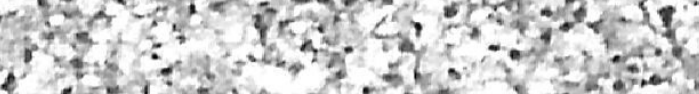

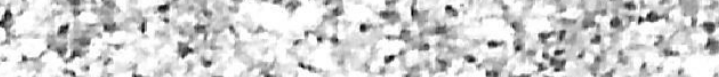

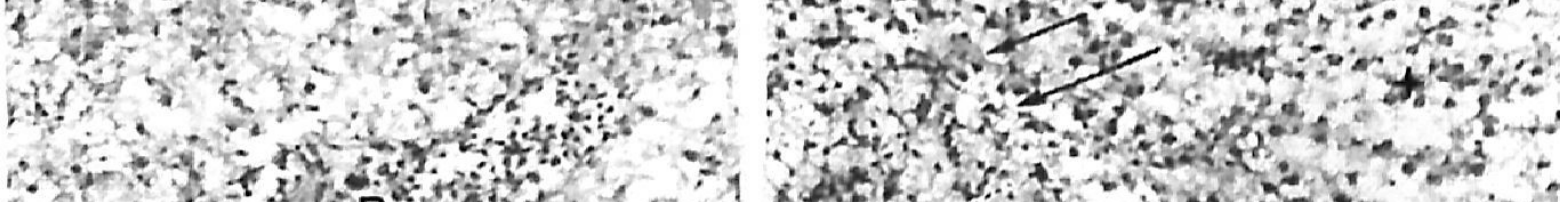
(2) Sum 28,5 a

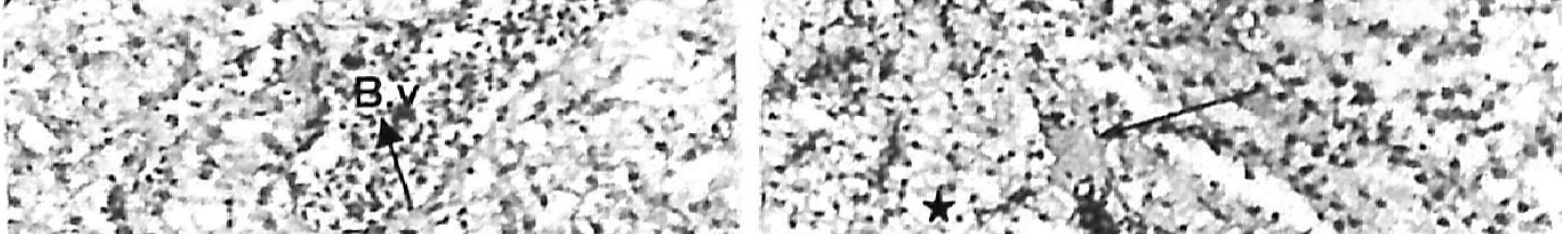

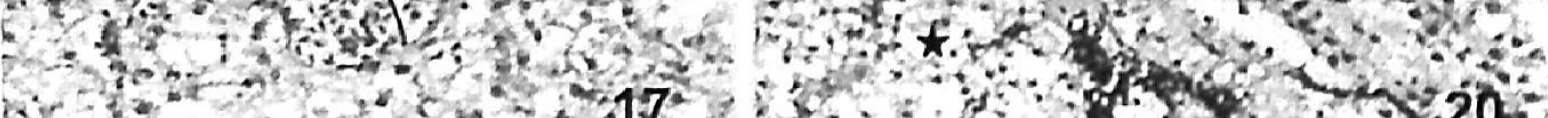

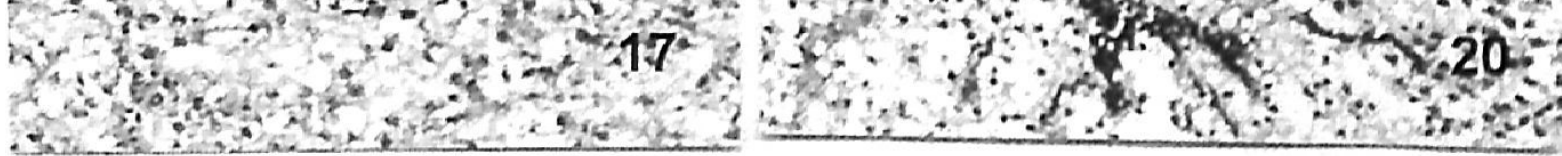


(2)

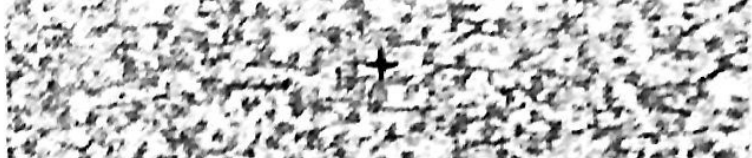

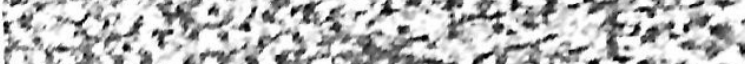

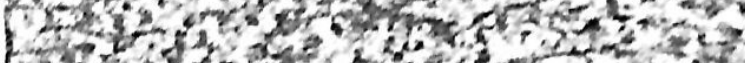

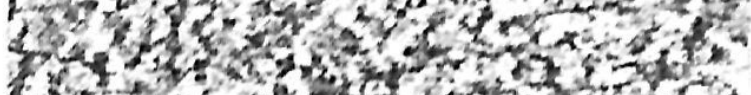

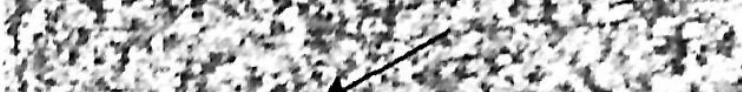

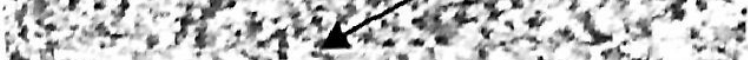

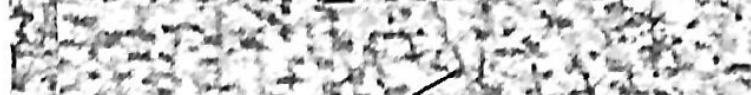

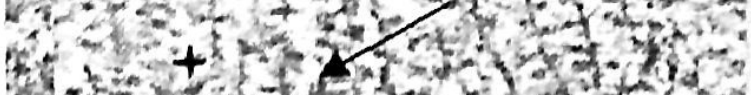

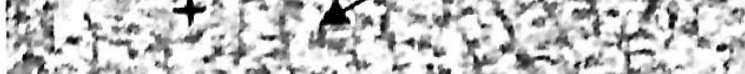

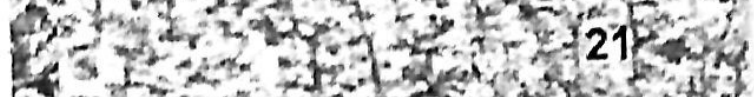

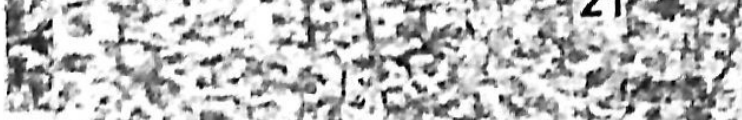

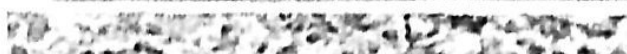

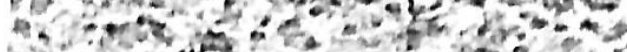

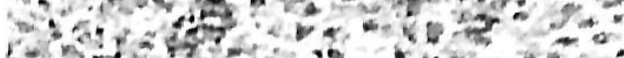

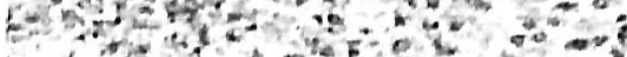

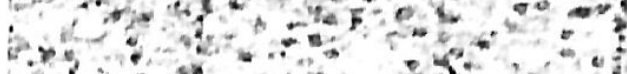
$020+20+3$

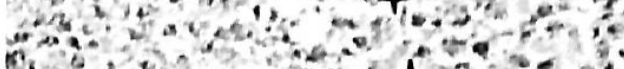

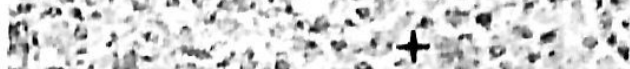

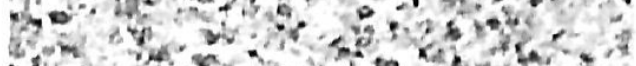

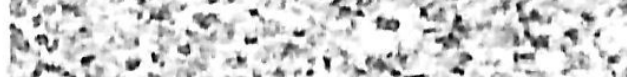

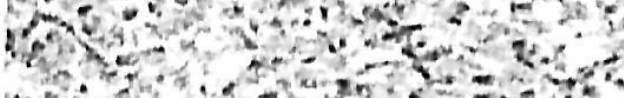

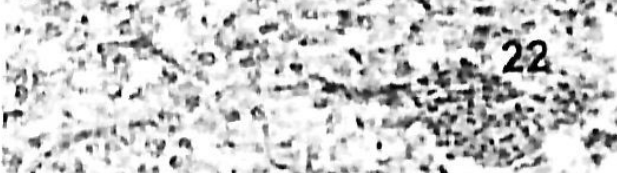

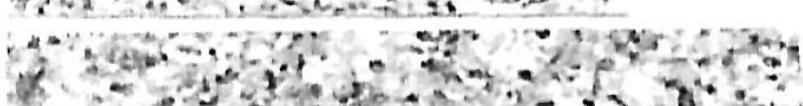

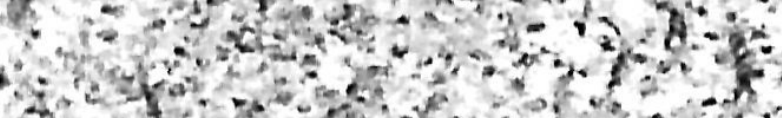

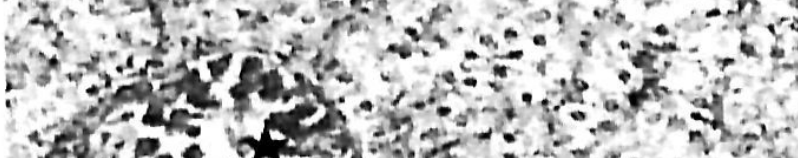

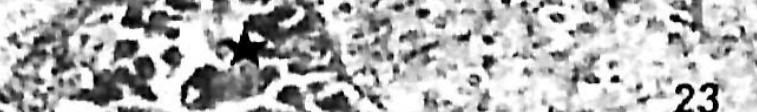

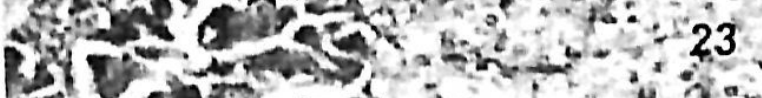
(5)

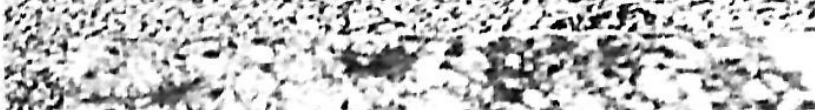

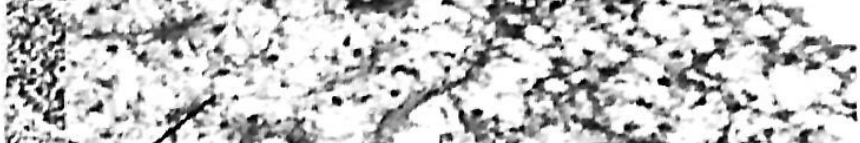

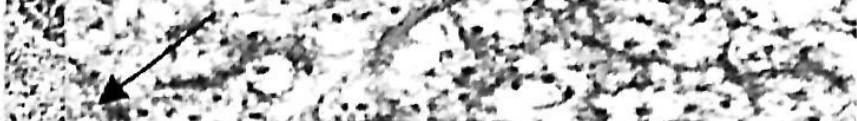

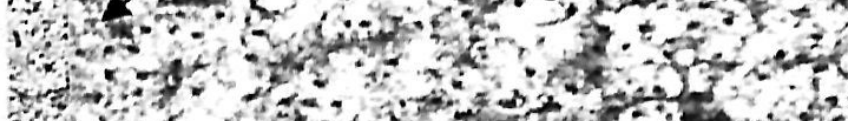

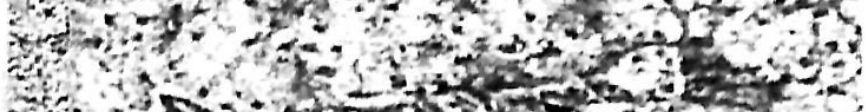

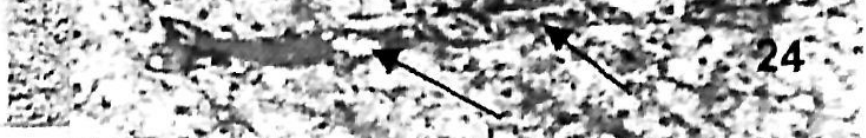

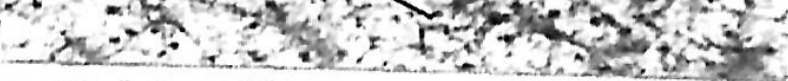

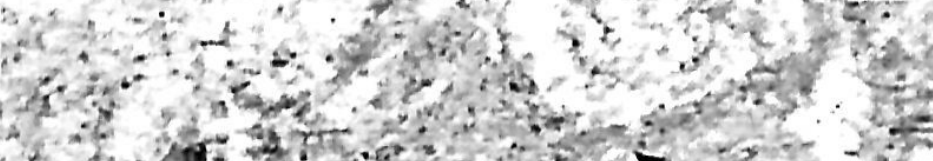

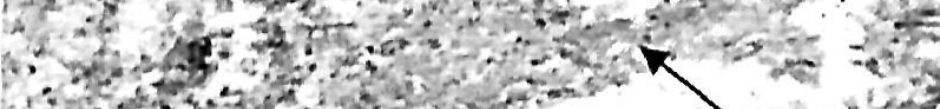

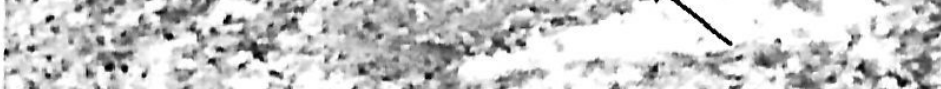

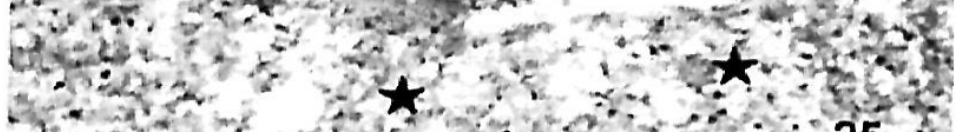

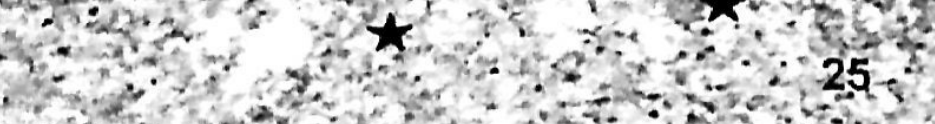

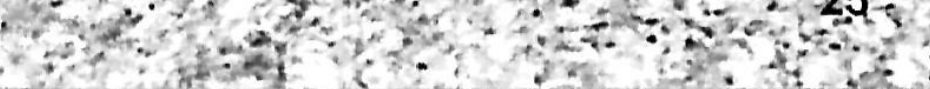

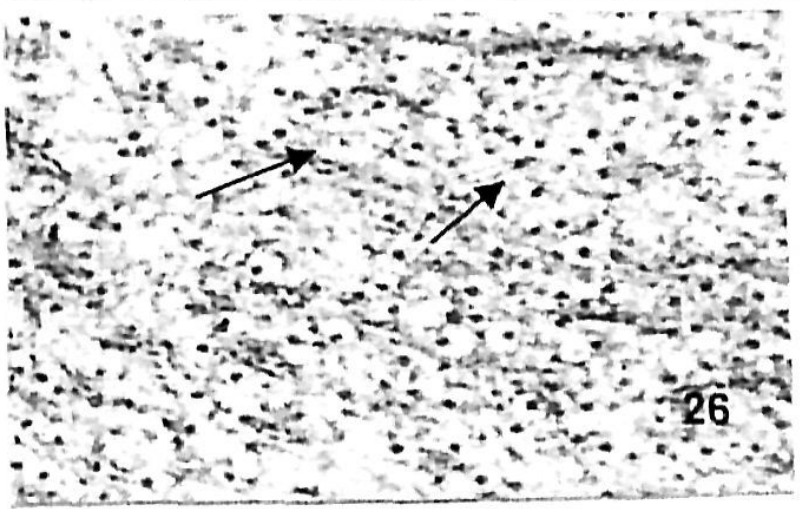

